\title{
Diversity of Biting Midges of the Genus Culicoides Latreille (Diptera: Ceratopogonidae) in the Area of the Yacyretá Dam Lake between Argentina and Paraguay
}

\author{
María M Ronderos/+ , Nancy M Greco*, Gustavo R Spinelli \\ Departmento Científico de Entomología, Museo de La Plata, Paseo del Bosque s/no., 1900 La Plata, Argentina \\ *CEPAVE (UNLP-CONICET), La Plata, Argentina
}

The Culicoides communities have been analyzed between 1993/1998 in the area influenced by the Yacyretá Dam Lake (Paraná River, Argentina-Paraguay). Adults of Culicoides were collected monthly by using CDC light traps exposed for $24 \mathrm{~h}$ in 9 sampling sites located at both margins of the river; 21 species were recorded. Highest values of species richness were recorded during 1993/1994, being Quiteria and Corpus the sites with the higest number of species (10 and 11, respectively). The species diversity was elevated in Quiteria, Zaimán, Candelaria, Santa Tecla, Capitán Meza and Corpus (Shannon's diversity index 1.0-1.9) while Corateí, Ituzaingó and Aguapey showed less richness and diversity. The more abundant species were C. insignis, C. venezuelensis, C. leopoldoi, C. limai, C. flinti, C. debilipalpis, C. paraensis and C. guttatus. C. insignis, potential vector of bluetongue virus (BTV) to domestic and wild rumiants in the Neotropical region, is the predominant species in the area and was the only species widely distributed. C. paraensis, a proven vector of Oropouche virus to humans, is a common and abundant species. C. pusillus and $\mathrm{C}$. lahillei, potential vectors of BTV and a filarial parasite, respectively, were occasionally collected. The taxonomic structure of communities was constant during the study period. The occasional species were not characteristic to one particular site and their presence could be related to non-intrinsic conditions.

Key words: diversity - Culicoides - Yacyretá Dam Lake - Argentina - Paraguay

The largest area influenced by the Yacyretá Dam Lake, located in the Paraná River between Argentina and Paraguay, offers adequate breeding sites for hematophagous nematocerous Diptera. The ceratopogonid biting midges of the genus Culicoides Latreille, which are well known as notorious blood sucking pests on man and animals throughout the world (Wirth et al. 1988, Greiner et al. 1990), are represented in the area by 22 species (Ronderos \& Spinelli 1998, in press). Some of these species are proven vectors of viruses in the Neotropical region, e.g. $C$. paraensis (Goeldi) transmitting "oropouche" virus (OROV) to humans (Pinheiro et al. 1982, Linley et al. 1983, Degallier et al. 1998, Mellor et al. 2000). Other species are potential vectors, e.g. C. insignis Lutz and $C$. pusillus Lutz for the bluetongue virus (BTV) to domestic and wild ruminants (Greiner et al. 1984, 1990, Homan et al. 1990, Tanya et al. 1992, Sáenz \& Greiner 1994, Mellor et al. 2000) and C. lahillei (Iches) for the filarial parasite Mansonella ozzardi Manson to humans in Northern Argentina (Shelley \& Coscarón 2001). Many of them, e.g. C. debilipalpis Lutz, C. lahillei and C. paraensis are also well known by the inhabitants of the area by their annoying disturbance of fishermen, farmers, and tourists at recreational resorts.

The Entidad Binacional Yacyretá supported the field work. ${ }^{+}$Corresponding author. Fax: +54-221-425727. E-mail: ronderos@museo.fcnym.unlp.edu.ar

Received 15 April 2002

Accepted 12 September 2002
In spite of the sanitary and economic relevance of the genus, and the adequate achieved knowledge on its taxonomy for the region (Ronderos \& Spinelli 1998), there is no information available on the major features of their communities. The area is characterized by the existence of several different breeding environments, so local variations in Culicoides assemblages are expected. Likewise, at the community level, the temporal structure of an assemblage may greatly change in terms of both, numbers and relative abundance of the species. Analyses of temporal constancy from assemblages are desirable in order to determine whether the patterns observed up to date are representative.

The aim of this paper is to describe and analyse the major features of the Culicoides communities, determining the species composition and the relative abundance and constancy of the potential vector species in the area influenced by the Yacyretá Dam Lake.

\section{MATERIALS AND METHODS}

Study area - The study area, located between $27^{\circ} \mathrm{S}$ and $28^{\circ} \mathrm{S}$ along the Paraná River (Fig. 1), is characterized by high relative humidity and an annual average temperature of $21.5^{\circ} \mathrm{C}$ (ranging between $15^{\circ} \mathrm{C}$ and $27^{\circ} \mathrm{C}$ ). Nine sampling sites were selected at both margins of the Paraná River, currently transformed in a dam lake, between Candelaria and Ituzaingó on its left shore (Argentina), and Capitán Meza and Corateí on its right shore (Paraguay). Most of them were located in natural environments of the subtropical forest corridors with abundant streams, being the ones located in Ituzaingó, Quiteria and Zaimán periurban or urban localities.

The stations were selected in order to obtain an adequate representation of both sides of the river, also con- 


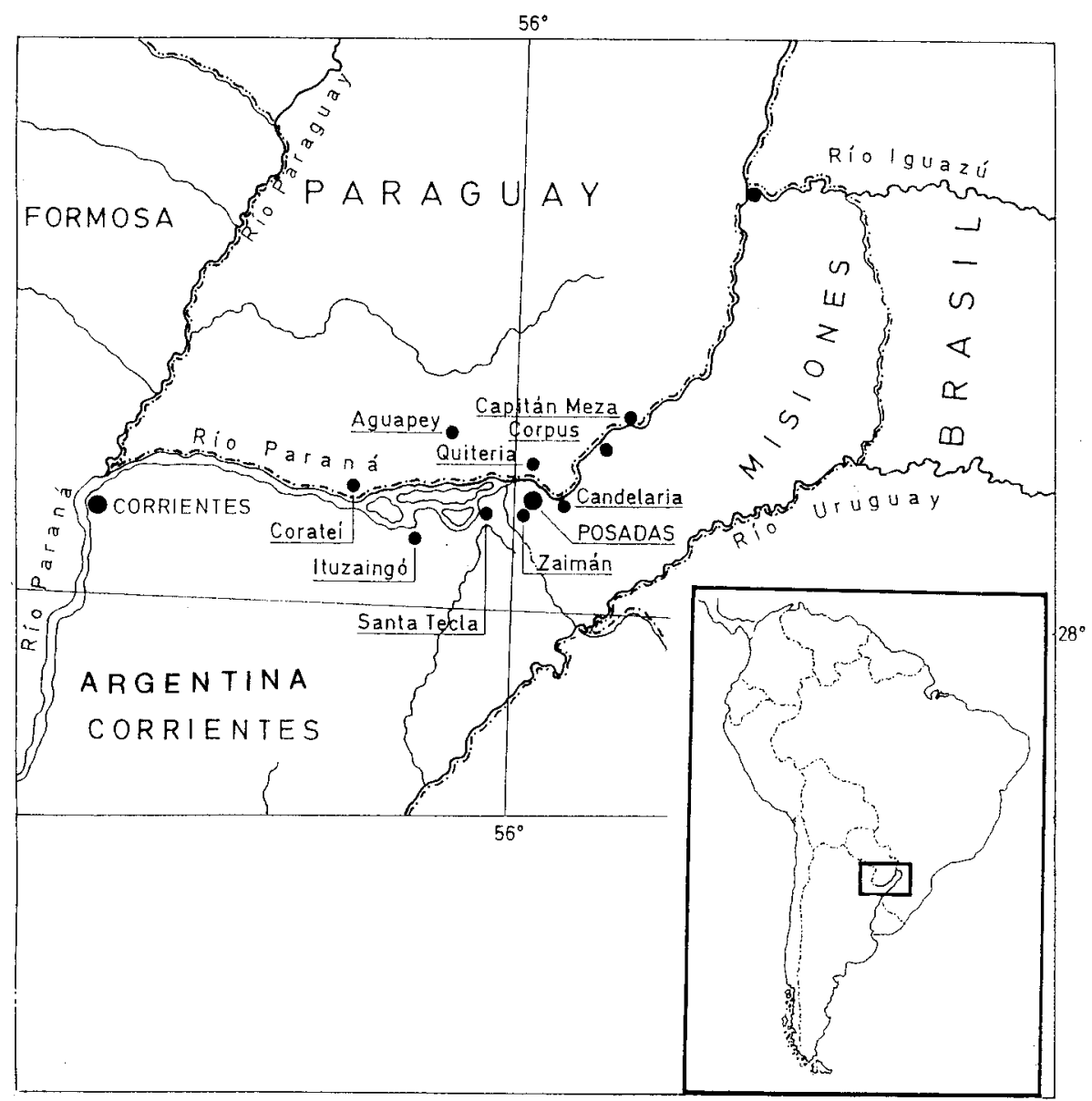

Fig. 1: area of the Yacyretá Dam Lake (Argentina, Paraguay). Sampling sites: Corateí, Ituzaingó, Aguapey, Santa Tecla, Quiteria, Zaimán, Candelaria, Capitán Meza and Corpus.

cerning their locations at similar stretches. In the particular case of Corpus and Corateí, they were selected considering that construction of an hydroelectric complex is projected between these two sites in the near future, so the obtained data could be available for future impact assessment.

Sampling of Culicoides - Adults of Culicoides were monthly collected by using CDC light traps (Service 1976) exposed at each sampling station for $24 \mathrm{~h}$. A portable automobile battery supplied a $12 \mathrm{v} / 15 \mathrm{w}$ light source. Biting midges were also attracted to the trap by a constant rate of $\mathrm{CO}_{2}$ liberation of $500 \mathrm{ml} / \mathrm{min}$. The individuals collected were preserved in isopropylic alcohol. The sampling periods ranged from July 1993 to June 1994 (9 sites), from July 1995 to June 1996 (9 sites), and 1997 and 1998 from February to September (4 sites). The abundance of the species in the four sites surveyed during the hole collected period (Corateí, Santa Tecla, Aguapey and Corpus) was analyzed for the study of temporal variations in the community structure. The collected specimens were deposited in the collection of the Museo de La Plata, La Plata, Argentina.

Data analysis - Relative abundance of Culicoides species for each study site and year was calculated as the abundance of each one in relation to the total abundance of all collected species. The species richness (total number of species in the communities) at each site for each year was estimated. The diversity was assessed by Shannon's diversity index (Begon et al. 1996).

In order to examine the distribution of the species in hierarchy groups over the entire region, they were ranked by frequency of site-year presence. The proportion of the species that were uncommon (present at $<25 \%$ of the 26 total site-years), intermediate (present at $>25$ and $<75 \%$ of the 26 total site-years) and widespread (present at $\geq$ $75 \%$ of the 26 total site-years) distributed was computed. The relative abundance of species in each hierarchy group was compared by the Mann-Whitney test (Zar 1996).

The constancy in the taxonomic structure of these communities was measured using Kendall's Coefficient of concordance (W) (Siegel 1991), based on the ranks of the abundance of the top four species among years in the four sites that were sampled during all the study period (Corateí, Santa Tecla, Aguapey and Corpus).

A binary matrix challenging the 21 species and the 9 collecting sites was organized based on the presence or absence of the Culicoides species in a given site. Euclidean distances were used to measure the distances among 
Culicoides communities. To explore the existence of a grouped distribution pattern among the species, a cluster analysis was conducted using the unweighted pair of group's method (Sneath \& Sokal 1973).

\section{RESULTS}

Twenty one species of Culicoides were captured during the entire sampling period. During 1993/1994 the predominant species were $C$. insignis, C. leopoldoi, C. limai, C. flinti and C. venezuelensis (98\%); in 1995/1996 C. insignis, C. leopoldoi, C. venezuelensis and C. limai (71\%); in 1997 C. insignis, C. debilipalpis, C. leopoldoi, C. paraensis (98\%), and in 1998 C. insignis and C. limai $(96 \%)$. Relative abundance, richness and diversity of species are presented in Tables I and II. Those species that only appeared in 1993/1994 showed a low relative abundance. Species richness and diversity were variable between years and sample sites. The highest values of species richness were recorded in Quiteria, Corpus, Santa Tecla and Capitán Meza. The species diversity was highest in Quiteria, Corpus, Santa Tecla, Capitán Meza, Zaimán and Candelaria. Corateí, Ituzaingó and Aguapey showed less richness and diversity. Richness and diversity decreased during 1998 at all sites.

The community structure is summarized in the Fig. 2, combining frequency and relative abundance of all collected species. There was a high number of species narrowly distributed (occasionally present), whose relative abundance ranged between 0.001 and 0.75 . Likewise, the intermediate species distribution (common and very common) showed significantly higher relative abundance (U $\left.=15, \mathrm{P}=0.015, \mathrm{n}_{1}=13, \mathrm{n}_{2}=7\right)$. C. insignis was the only species widely distributed (abundant).

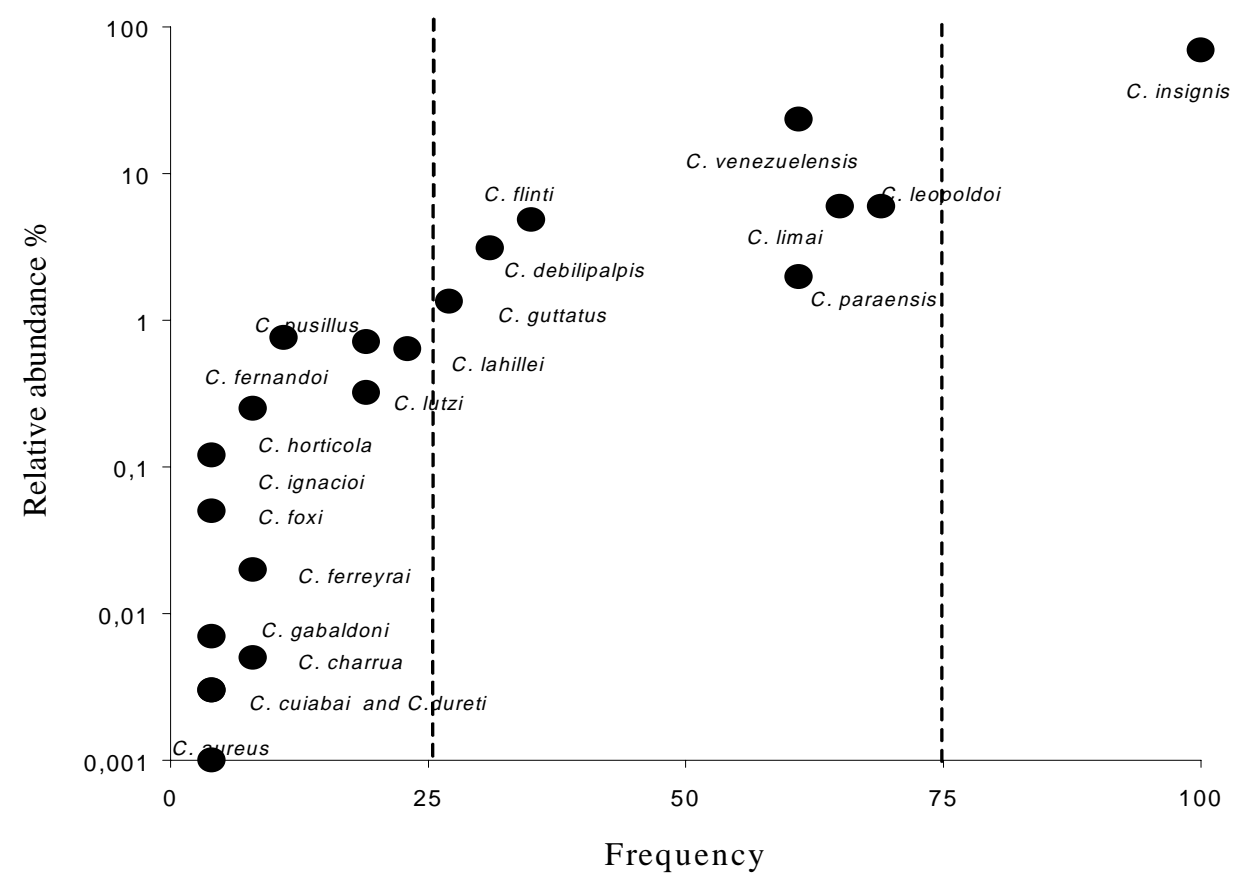

Fig. 2: frequency and relative abundance of Culicoides species in the area of the Yacyretá Dam Lake. Frequency of 0-25\%, 25-75\% and 75-100\% correspond to occasionally, common and very common, and abundant species, respectively.
The analysis of the relative abundance between 1993 and 1998 (Table III) showed a little variation among the four top ranked species, $C$. insignis being the most abundant. Considering only these four species, the taxonomic structure of communities was constant along the studied period, except for Santa Tecla (Corateí: $\mathrm{W}=0.69, \mathrm{P}<0.05$; Aguapey: $\mathrm{W}=0.93, \mathrm{P}\langle 0.01$; Santa Tecla: $\mathrm{W}=0.53, \mathrm{P}\rangle$ 0.05 and Corpus: $\mathrm{W}=0.74, \mathrm{P}<0.05$ ).

According to the presence of the different species along the sampling period, the cluster analyses indicated two groups (Fig. 3). One of them showed an increasing gradation of sites and the distance between them was determined by the distribution of occasional species. The other group, represented by the nearest localities Corateí and Ituzaingó, is characterized by the presence of the three common and abundant species $(C$. insignis, $C$. venezuelensis and C. paraensis) showing low richness as well as low diversity.

\section{DISCUSSION}

A high percentage $(64.7 \%)$ of the 34 species recorded from Argentina by Ronderos and Spinelli (in press) is represented in the studied communities herein.

From the results, and considering the species real or potential involvement in virus transmission, it is clear that C. insignis is the dominant species. C. paraensis is a common and abundant species associated to $C$. insignis and $C$. venezuelensis in Corateí and Ituzaingó. $C$. pusillus is narrowly distributed (Candelaria, Capitán Meza and Corpus) and shows a moderate relative abundance. $C$. lahillei is also occasional (Santa Tecla, Quiteria, Capitán Meza and Corpus).

C. insignis has also been reported previously as predominant species in the area of Salto Grande Dame Lake 
TABLE I

Relative abundance of collected Culicoides spp. at each sampling site of the area of the Yacyretá Dam Lake in 1993/1994 and 1995/1996

\begin{tabular}{|c|c|c|c|c|c|c|c|c|c|c|c|c|c|c|c|c|c|c|}
\hline \multirow{2}{*}{$\begin{array}{l}\text { Years } \\
\text { Sites }\end{array}$} & \multicolumn{9}{|c|}{ 1993/1994 } & \multicolumn{9}{|c|}{$1995 / 1996$} \\
\hline & 1 & 2 & 3 & 4 & 5 & 6 & 7 & 8 & 9 & 1 & 2 & 3 & 4 & 5 & 6 & 7 & 8 & 9 \\
\hline \multicolumn{19}{|l|}{ Species } \\
\hline C. aureus & & 0.03 & & & & & & & & & & & & & & & & \\
\hline C. charrua & & & 0.08 & & & & & & 0.05 & & & & & & & & & \\
\hline C. cuiabai & & 0.01 & & & & & & & & & & & & & & & & \\
\hline C. debilipalpis & & & & & & & & & & & 0.36 & 0.23 & & 1.47 & 5.00 & & 2.27 & 12.50 \\
\hline C. dureti & & & & & 0.12 & & & & & & & & & & & & & \\
\hline C. fernandoi & & & & 6.40 & & & 9.10 & & & & & & & & & & & 4.16 \\
\hline C. ferreyrai & & & & & & 0.70 & & & 0.05 & & & & & & & & & \\
\hline C. flinti & & & & & & 48.90 & 0.90 & 55.80 & 3.90 & 1.72 & & & 5.42 & 5.80 & & & 2.27 & \\
\hline \multicolumn{19}{|l|}{ C. foxi } \\
\hline C. gabaldoni & & & & & 0.18 & & & & & & & & & & & & & \\
\hline C. guttatus & & & & & 0.44 & & 1.80 & & 5.60 & & & & & 2.94 & & 17.30 & 6.81 & \\
\hline C. horticola & & & & 6.40 & & & & & 1.10 & & & & & & & & & \\
\hline C. ignacioi & & & & 3.20 & & & & & & & & & & & & & & \\
\hline C. insignis & 90.00 & 99.90 & 91.70 & 38.70 & 57.30 & 47.60 & 46.70 & 30.80 & 79.70 & 65.00 & 99.00 & 83.40 & 85.20 & 34.00 & 45.00 & 36.90 & 36.30 & 41.70 \\
\hline C. lahillei & & & & 3.20 & 0.60 & & & 0.80 & 0.05 & & & & & 2.90 & & & & \\
\hline C. leopoldoi & & & 3.60 & & 16.40 & & 22.20 & 10.80 & 1.70 & 5.20 & & 10.20 & 0.80 & 2.90 & 15.00 & 19.50 & 34.10 & 8.30 \\
\hline C. limai & & & 2.10 & 22.50 & 18.20 & 2.00 & 17.30 & & 4.50 & & & 5.80 & 0.80 & 5.80 & 10.00 & 17.30 & 4.50 & 20.80 \\
\hline C. lutzi & & & 1.90 & 3.22 & & 0.70 & & 0.80 & & 1.70 & & & & & & & & \\
\hline C. paraensis & 3.00 & 0.02 & & 12.90 & 1.50 & & & 0.80 & 0.05 & 1.70 & 0.40 & & 0.80 & 8.80 & & 2.20 & 2.30 & 4.16 \\
\hline C. pusillus & & & & & & & 1.50 & & 1.10 & & & 0.20 & & & & 6.50 & 9.10 & \\
\hline C. venezuelensis & 6.10 & 0.02 & 0.50 & 3.22 & 4.90 & & 0.40 & & & 24.00 & & & 6.90 & 34.00 & 25.00 & & 2.30 & 8.30 \\
\hline No. of individuals & 65 & 11,223 & 1,236 & 30 & 1,582 & 147 & 451 & 120 & 177 & 58 & 273 & 429 & 139 & 70 & 20 & 46 & 44 & 24 \\
\hline Richness & 3 & 6 & 6 & 9 & 10 & 5 & 8 & 6 & 11 & 6 & 3 & 5 & 6 & 9 & 5 & 6 & 9 & 7 \\
\hline Diversity & 0.37 & 0.01 & 0.39 & 1.76 & 1.21 & 1.00 & 1.90 & 1.53 & 0.58 & 0.98 & 0.05 & 0.58 & 0.59 & 1.65 & 1.37 & 1.55 & 1.65 & 1.63 \\
\hline
\end{tabular}

Sampling sites: 1: Corateí, 2: Ituzaingó, 3: Aguapey, 4: Santa Tecla, 5: Quiteria, 6: Zaimán,7: Candelaria, 8: Capitán Meza, 9: Corpus 
TABLE II

Relative abundance of collected Culicoides spp. at each sampling site of the area of the Yacyretá Dam Lake in 1997 and 1998. Sampling sites: 1: Corateí, 3: Aguapey, 4: Santa Tecla, 9: Corpus

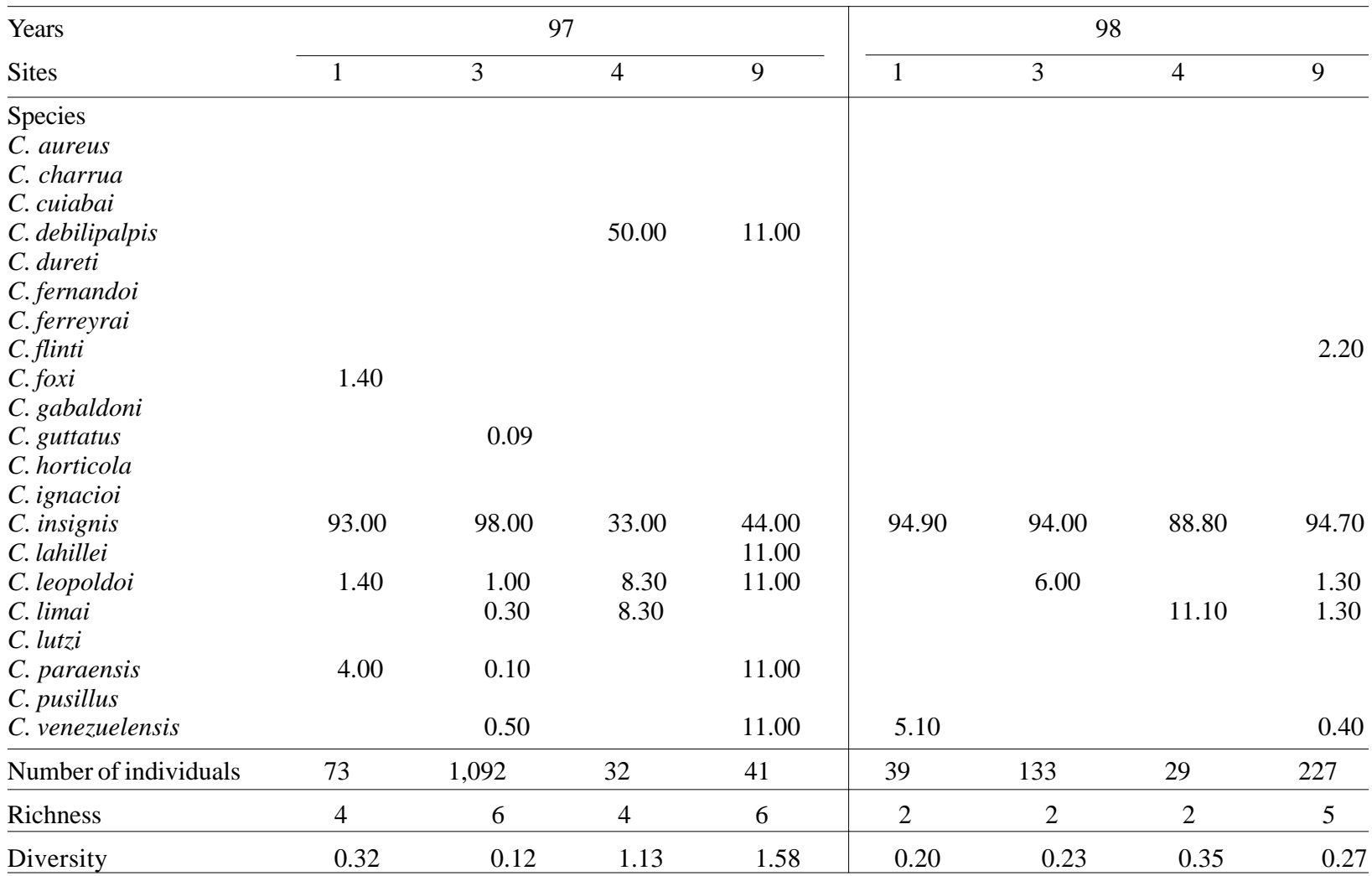

TABLE III

Relative abundance of predominant Culicoides spp. in Corateí, Aguapey, Santa Tecla and Corpus

\begin{tabular}{lcr}
\hline Species & Mean & SD \\
\hline & Coratei & \\
C. insignis & 85.70 & 13.90 \\
C. venezuelensis & 8.80 & 10.50 \\
C. leopoldoi & 2.44 & 1.64 \\
C. paraensis & 2.18 & 1.72 \\
& Aguapey & \\
C. insignis & 91.78 & 6.13 \\
C. leopoldoi & 5.21 & 3.93 \\
C. limai & 2.04 & 2.68 \\
C. venezuelensis & 0.26 & 0.30
\end{tabular}

Santa Tecla

C. insignis

61.45

C. debilipalpis

12.50

10.69

5.54

Corpus

C. insignis

65.02

6.65

5.58

C. leopoldoi

4.93 between Argentina and Uruguay (Spinelli and Ronderos 1991). Besides, communities associated to cattle showed C. insignis as the most important species (Kramer et al. 1985, Sáenz and Greiner 1994 ).

The highest values of species richness and diversity were registered in the localities situated in the northern part of the study area. This could be related to the existence in the mentioned zone of subtropical forest habitats housing different kinds of breeding sites for Culicoides spp. Mullen and Hribar (1988), Hribar and Mullen (1991), Murphree and Mullen (1991), and Hribar (1993) reported tree holes, stump holes, and other rotting woods as common environments for immature stages of several species of the genus.

Common (and rare) species tended to be typically common (and rare) from year to year, during the entire study. Each assemblage was reasonably predictable. Some species were not characteristic of any particular site and their presence could be related to non-intrinsic conditions (i.e., high temperature and abundant rains in 1993-1994).

More ecological studies at the population and community levels are necessary to describe and to explain the abundance and relative importance of the potential vectors species in the communities of this region, especially considering the roles of $C$. insignis and $C$. paraensis as vectors of BTV and OROV, respectively.

\section{ACKNOWLEDGEMENTS}

To Mrs Mónica Caviglia for English revision. 


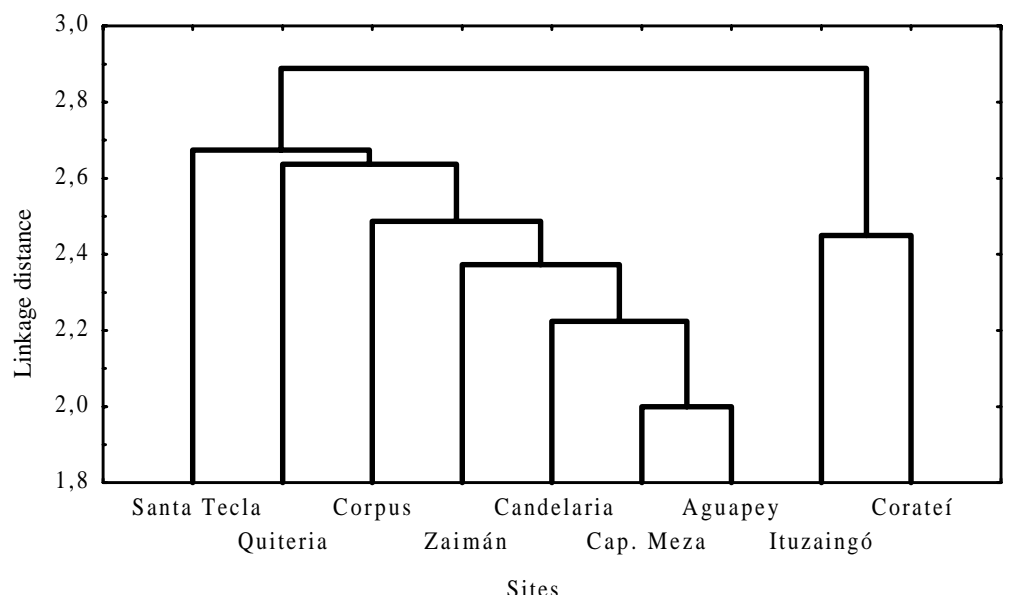

Fig. 3: Tree diagram (Euclidean distances) for presence or absence of the Culicoides species in the sampling sites of the area of the Yacyretá Dam Lake.

\section{REFERENCES}

Begon M, Harper JL, Townsend CR 1996. Ecology. Individuals, Populations and Communities, Blackwell Science, UK, $1068 \mathrm{pp}$.

Degallier N, Travassos da Rosa APA, Herve JP, Vasconcelos PFC, Travassos da Rosa JFS, Sa' Filho GC, Pinheiros, FP 1998. Evolutionary aspects of the ecology of arboviruses in Brasilian Amazonian, South America. In APA Travassos da Rosa, PFC. Vasconcelos, JFS Travassos da Rosa (eds), An Overview of Arbovirilogy in Brazil and Neighbouring Countries, Instituto Evandro Chagas, Belém, p. 42-60.

Greiner EC, Garris GI, Rollo RT, Knausenberguer WI, Jones JE, Gibbs EPJ 1984. Preliminary studies on the Culicoides spp. as potential vectors of bluetongue in the Caribbean Region. Prev Vet Med 2: 389-399.

Greiner EC, Knausenberger WI, Mesersmith M, Kramer WL, Gibbs EPJ 1990. Culicoides spp. (Diptera: Ceratopogonidae) associated with cattle in St. Croix, Virgin Islands, and their relevance to bluetongue viruses. J Med Ent 27: 1071-1073.

Homan EJ, Thompson LH, Barreto CH, Oviedo MT, Gibbs EPJ, Greiner EC 1990. Epidemiologic study of bluetongue viruses in Central America and the Caribbean: 1986-1988. $J$ Am Vet Med Assoc 51: 1089-1094.

Hribar LJ 1993. Mouthpart morphology and feeding behavior of biting midge larvae (Diptera: Ceratopogonidae). In CW Schaefer, RAB Leshen (eds), Functional Morphology of Insect Feeding, Thomas Say Publications in Entomology: Proceedings Entomological Society of America, USA, p. 44-57.

Hribar LJ, Mullen GR 1991. Alimentary tract contents of some biting midge larvae (Diptera: Ceratopogonidae). J Entomol Sci 26: 429-435.

Kramer WL, Greiner EC, Gibbs EPJ 1985. Seasonal variations in population size, fecundity, and parity rates of Culicoides insignis (Diptera: Ceratopogonidae) in Florida, USA. $J$ Med Entomol 22: 163-169.

Linley JR, Hoch AL, Pinheiro FP 1983. Biting midges (Diptera: Ceratopogonidae) and human health. J Med Entomol 20: 347-364.

Mellor PS, Boorman J, Baylis M 2000. Culicoides biting midges: their role as arbovirus vectors. Annu Rev Entomol 45: 307-340.

Mullen GR, Hribar LJ 1988. Biology and feeding behavior of ceratopogonid larvae (Diptera: Ceratopogonidae) in North
America. Bull Soc Vector Ecol 13: 60-81.

Murphree CS, Mullen GR 1991. Comparative larval morphology of the genus Culicoides Latreille (Diptera: Ceratopogonidae) in North America with a key to species. Bull Soc Vector Ecol 16: 269-299.

Pinheiro FP, Travassos da Rosa APA, Gomes ML, Le Duc JW, Hoch AL 1982. Transmission of Oropouche virus from man to hamster by the midge Culicoides paraensis. Science 215: 1251-1253.

Ronderos MM, Spinelli GR 1998. Las especies de Culicoides en el área de influencia de la represa de Yacyretá (Diptera: Ceratopogonidae). Rev Soc Entomol Argent 57: 79-83.

Ronderos MM, Spinelli GR. Los Culicoides de la Argentina: clave de especies y nuevos registros (Diptera: Ceratopogonidae). Actualizaciones en Entomo-epidemiología Argentina (in press).

Sáenz MR, Greiner EC 1994. Culicoides aspirated from cattle in Costa Rica, Honduras, Panama and Puerto Rico, and their role as potential vectors of the bluetongue viruses. Med Vet Ent 8: 15-19.

Service MW 1976. Mosquito Ecology, Field Sampling Method, Applied Science Publishers, London, 583 pp.

Shelley AJ, Coscarón S 2001. Simuliid blackflies (Diptera: Simuliidae) and ceratopogonid midges (Diptera: Ceratopogonidae) as vectors of Mansonella ozzardi (Nematoda: Onchocercidae) in Northern Argentina. Mem Inst Oswaldo Cruz 96: 451-458.

Siegel S 1991. Estadística no Paramétrica Aplicada a las Ciencias de la Conducta, Trilla, México, 344 pp.

Sneath PH, Sokal RR 1973. Numerical Taxonom, Freeman, San Francisco, $573 \mathrm{pp}$

Spinelli GR, Ronderos MM 1991. Los polvorines del género Culicoides en areas de influencia de la represa de Salto Grande (Diptera: Ceratopogonidae). Neotrópica 37: 83-94.

Tanya VN, Greiner EC, Gibbs EPJ 1992. Evaluation of Culicoides insignis (Diptera: Ceratopogonidae as a vector of bluetongue virus. Vet Microbiol 31: 1-14.

Wirth WW, Dyce AL, Spinelli GR 1988. An atlas of wing photographs, with a summary of the numerical characters of the Neotropical species of Culicoides (Diptera: Ceratopogonidae). Contrib Amer Entomol Inst 25: 1-72.

Zar JF 1996. Biostatistical Analysis, 3rd ed., Prentice-Hall, USA, $827 \mathrm{pp}$. 